\title{
Plant regeneration via somatic embryogenesis from root explants of Hevea brasiliensis
}

\author{
Quan-Nan Zhou ${ }^{1}$, Ze-Hai Jiang ${ }^{2}$, Tian-Dai Huang ${ }^{1}$, Wei-Guo Li ${ }^{1}$, Ai-Hua Sun ${ }^{1}$, Xue-Mei Dai ${ }^{1}$ and \\ Zhe Li ${ }^{1 *}$
}

${ }^{1}$ Rubber Research Institute, Chinese Academy of Tropical Agricultural Sciences, State Center for Rubber Breeding, State Engineering and Technology Research Center for Key Tropical Crops, Danzhou 571737, China.

${ }^{2}$ College of Agronomy, Hainan University, Danzhou 571737, China.

Accepted 30 August, 2010

A system for induction of callus and plant regeneration via somatic embryogenesis from root explants of Hevea brasiliensis Muell. Arg. clone Reyan 87-6-62 was evaluated. The influence of plant growth regulators (PGRs) including 2,4-dichlorophenoxyacetic acid (2,4-D), 6-benzylaminopurine (6-BA) and kinetin (KT) on callus induction of root explants from in vitro plantlets were studied. The results showed that the highest induction frequency of embryogenic callus emerged on Murashige and Skoog (MS) medium supplemented with $1 \mathrm{mg} / \mathrm{l} \mathrm{KT,} 0.2 \mathrm{mg} / \mathrm{l}$ 6-BA without 2,4-D. Mean of 4 somatic embryos per embryogenic callus were obtained and approximately $11.8 \%$ of them developed into plantlets. The regenerated plantlets were successfully transplanted to sand bed. The plant regeneration system established in this study will facilitate mass propagation and may be applied to culture the roots of high-yielding rubber trees.

Key words: Hevea brasiliensis Muell. Arg., root explants, callus, somatic embryogenesis, regeneration.

\section{INTRODUCTION}

The rubber tree (Hevea brasiliensis) which is the main source of natural rubber is a heterozygous perennial tree with a long reproductive maturity. This makes improvement via conventional breeding very difficult. In spite of the intraclonal heterogeneity of the rootstocks produced from seeds, the $H$. brasiliensis is propagated mostly by grafting.

The interaction between rootstock and scion of grafted rubber tree affects growth, yield, as well as the physiological and biochemical characteristics of rubber trees (Ahmad, 1999; Sobhana et al., 2001; Huang and Lin, 2003, trees have been found, whose annual dry rubber

\footnotetext{
*Corresponding author. E-mail: lizhecn@yahoo.cn.
}

Abbreviations: PGRs, Plant growth regulators; 2,4-D, 2,4-dichlorophenoxyacetic acid; 6-BA, 6-benzylaminopurine; KT, kinetin; MS, Murashige and Skoog; NAA, a-naphthalene acetic acid; $\mathbf{G A}_{3}$, gibberellic acid; IAA, indole-3-acetic acid. output Sobhana et al., 2001; Huang and Lin, 2003). Yunnan province of China, some high-yielding rubber can reach over $100 \mathrm{~kg}$. Micropropagation of the rootstocks of high-yielding rubber trees has great significance for uniform growth and largely increases rubber output. The roots of the rootstocks can be a good explant source.

Somatic embryogenesis is a rapid and efficient vegetative propagation method. Plant regeneration via somatic embryogenesis in $\mathrm{H}$. brasiliensis has been reported using several explants such as immature anther (Wang et al., 1980), inner integument of seed (Carron, 1981) and immature inflorescence (Sushamakumari et al., 2000).

The objective of the current research is to establish a plant regeneration system via somatic embryogenesis from root explants in $H$. brasiliensis. The establishment of the system will be helpful to micropropagate high-yielding $H$. brasiliensis using the roots as explants and improve rubber production largely. In this study, the influences of 2,4-dichlorophenoxyacetic acid (2,4-D), 6-benzylaminopurine (6-BA) and kinetin (KT) on callus induction were 
investigated by orthogonal experimental design.

\section{MATERIALS AND METHODS}

\section{Plant materials}

Roots of in vitro plantlets from $H$. brasiliensis clone Reyan 87-6-62 were used as the source of explants. The plantlets were derived from immature anthers of the clone on modified Murashige and Skoog (MS) medium, and the immature anthers were from the experimental field of the Chinese Academy of Tropical Agricultural Sciences.

\section{Callus induction and proliferation}

Roots of the clone, Reyan 87-6-62, were dissected from in vitro plantlets and cut into $10-15 \mathrm{~mm}$ using a sharp sterilized blade. The explants were cultured on MS medium supplemented with different concentrations of 2,4-D (0, 2, 5 and $10 \mathrm{mg} / \mathrm{l}), \mathrm{KT}(1,3,5$ and $10 \mathrm{mg} / \mathrm{l})$ and 6 -BA $(0,0.2,0.5$ and $1 \mathrm{mg} / \mathrm{l})$. The $\mathrm{pH}$ of the medium was adjusted to 5.8 and all media were autoclaved for $20 \mathrm{~min}$ at $121^{\circ} \mathrm{C}$. 10 roots were cultured in one Petri dish containing $30 \mathrm{ml}$ medium. Cultures were incubated at $28 \pm 2^{\circ} \mathrm{C}$ under darkness. The explants were transferred into fresh medium every 4 weeks under the same culture conditions. The callus was subcultured and transferred to fresh medium every 4 weeks under the same culture conditions.

\section{Somatic embryogenesis and plant regeneration}

In order to obtain somatic embryos, the embryogenic callus were transferred into embryo-induction medium and cultured in darkness at $28 \pm 2^{\circ} \mathrm{C}$ for 4 weeks. The embryos were obtained after culturing for 4 weeks. The embryo-induction medium comprised of MS medium supplemented with $1.0 \mathrm{mg} / \mathrm{l}$ 6-BA, $3.0 \mathrm{mg} / \mathrm{l} \mathrm{KT}, 0.2 \mathrm{mg} / \mathrm{l}$ a-naphthalene acetic acid (NAA) and $0.05 \mathrm{mg} / \mathrm{l}$ gibberellic acid $\left(\mathrm{GA}_{3}\right)$.

Mature somatic embryos were transplanted into test tubes containing $30 \mathrm{ml} \mathrm{MS}$ medium supplemented with $0.5 \mathrm{mg} / \mathrm{l} \mathrm{KT}, 0.2$ $\mathrm{mg} / \mathrm{l}$ indole-3-acetic acid (IAA), $0.3 \mathrm{mg} / \mathrm{l} \mathrm{GA}_{3}$ and incubated in a growth room under the conditions of $28 \pm 2^{\circ} \mathrm{C}$, humidity $(60 / 70 \%)$, 12-h light:12-h dark photoperiod and transferred into fresh medium every 4 weeks. About 8 weeks later, the plantlets were obtained in the test tubes.

\section{Statistical analysis}

In this study, the orthogonal design of $L_{16}\left(4^{5}\right)$ was used and treatments were repeated three times. The data were analyzed by means of analysis of variance (ANOVA) on the statistical package of SAS program (Version 9.0. The means were analyzed by Duncan's multiple range tests $(P=0.05)$ to evaluate the effects of different concentrations of 2,4-D, KT and 6-BA on callus induction.

\section{RESULTS}

\section{Induction of callus and proliferation}

In order to evaluate the effects of plant growth regulators
(PGRs) on callus induction from root explants (Figure 1a), sixteen induction media based on MS medium containing different concentrations of 2,4-D, KT and 6-BA were designed with orthogonal design. In this study, it was found that callus was not induced from the explants on the medium of $\mathrm{MS}_{1}$ devoid of 2,4-D, KT and 6-BA (Table 1). These explants showed either green or intense oxidation after 4 weeks. In contrast, callus was formed in other fifteen media of $\mathrm{MS}_{2}-\mathrm{MS}_{16}$ whose nature of friability and compactness differed depending on 2,4-D, KT and 6-BA concentrations, resulting in 3 types of callus according to the method of Jayasree et al. (1999): Type I, loose, soft and gray; type II, compact, hard and pale yellow; and type III, granular, friable and canary yellow (Figure 1b). Type I callus was obtained on $\mathrm{MS}_{2}-\mathrm{MS}_{16}$ medium containing different concentrations of PGRs, while type II was obtained on $\mathrm{MS}_{2}-\mathrm{MS}_{14}$. It was noted that the frequency of type I callus produced was highest $(28.33 \%)$ on $\mathrm{MS}_{15}$ medium with $10 \mathrm{mg} / \mathrm{l}$ 2,4-D, $3 \mathrm{mg} / \mathrm{KT}$ and $0.2 \mathrm{mg} / \mathrm{l} \mathrm{6-BA}$, while type II (18.01\%) was on $\mathrm{MS}_{11}$ medium containing 5 $\mathrm{mg} / \mathrm{l} 2,4-\mathrm{D}$ and $3 \mathrm{mg} / \mathrm{KT}$ without 6-BA. Type I callus was non-embryogenic in nature and could not be induced into embryo. Sporadic frequency of type II callus could be induced into embryos (Table 3). In this experiment, it was found that type III callus was induced on $\mathrm{MS}_{2}, \mathrm{MS}_{6}, \mathrm{MS}_{8}$ $\mathrm{MS}_{10}$ and $\mathrm{MS}_{14}$ medium. Furthermore, the highest frequency of type III callus was up to $51.90 \%$ in the combination of $1 \mathrm{mg} / \mathrm{l} \mathrm{KT}, 0.2 \mathrm{mg} / \mathrm{l}$ 6-BA with 2,4-D absence $\left(\mathrm{MS}_{2}\right)$. Among the different combinations of different PGRs used, the frequency of three types of callus induced fluctuated at $0-28.33,0-18.01$ and 0 $51.90 \%$, respectively for type I, type II and type III. Further variance analysis by SAS program showed that 2,4-D ( $F=$ 30.00 ) plays a key role in type III callus formation, followed by 6-BA $(F=9.43)$ and $\mathrm{KT}(\mathrm{F}=4.92)$.

Significant differences for the frequencies of the three types of callus induced were tested by variance analysis among PGRs concentrations of 2,4-D ( $p=0.05), K T(p=$ $0.05)$ and $6-B A(p=0.05)$ (Table 2$)$. The results indicated that high concentration of 2,4-D promoted type I callus formation, whereas it inhibited type III. The greatest frequency of type I callus was achieved at $10 \mathrm{mg} / \mathrm{l} 2,4-\mathrm{D}$ at $28.33 \%$, while type III was without $2,4-\mathrm{D}$. The frequency of type II callus reached $19.62 \%$ at $5 \mathrm{mg} / \mathrm{l} 2,4-\mathrm{D}$. For $\mathrm{KT}$, the frequency of type I callus had no significant differences when 2,4-D concentration was, respectively, 1,3 and 5 $\mathrm{mg} / \mathrm{l}$. Different concentrations of KT had little influences on the frequency of type II callus. However, significant differences were found on type III and the optimal frequency was $15.51 \%$ at $1 \mathrm{mg} / \mathrm{l} \mathrm{KT}$. When 6-BA concentration was 0.2 and $1 \mathrm{mg} / \mathrm{l}$, the highest frequency was obtained for type I and type II, respectively. For type III, high frequency callus was induced at 0.2 or $0.5 \mathrm{mg} / \mathrm{l}$ 6-BA. According to the above results, the best combination of PGRs was complemented with $1 \mathrm{mg} / \mathrm{l} \mathrm{KT}, \quad 0.2$ $\mathrm{mg} / \mathrm{l}$ 


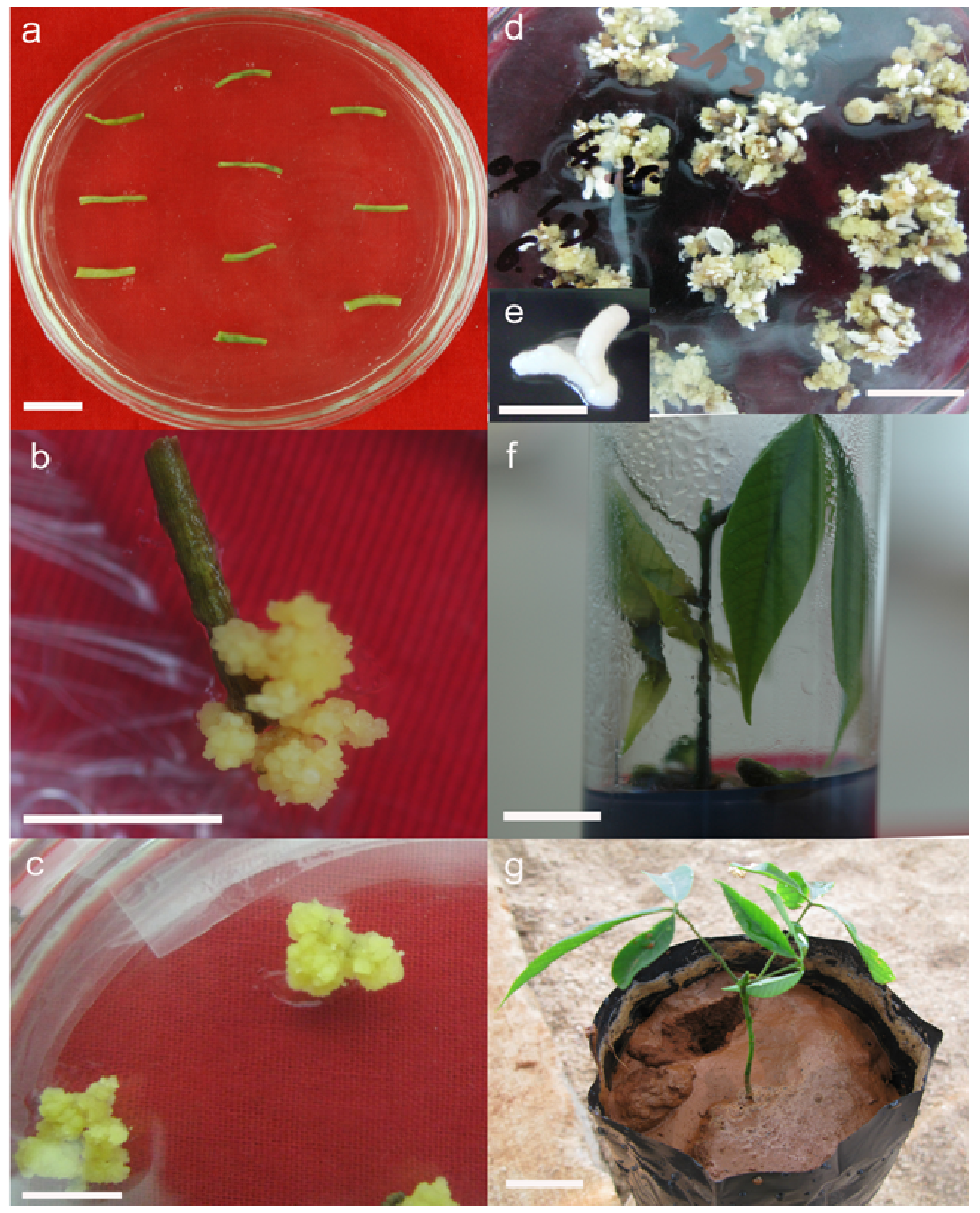

Figure 1. Somatic embryogenesis and plant regeneration from root explants of $H$. brasiliensis. a, The roots of plantlets derived from immature anthers of the clone Reyan 87-6-62; b, callus induced from root on $\mathrm{MS}_{2}$ medium; c, proliferation of callus; $d$, cotyledon embryo emerged from callus; e, mature cotyledon embryos; $f$, plant regeneration from mature cotyledon embryos; g, successful soil transfer of regenerated plants. Scale bars represent $0.5 \mathrm{~cm} \mathrm{(b,e),} 1 \mathrm{~cm}(\mathrm{a}, \mathrm{c}, \mathrm{d}$ and f), and $3 \mathrm{~cm}$ (g), respectively. 
Table 1. The variance analysis of the orthogonal experiment for callus induced from root explants of $H$. brasiliensis clone Reyan 87-6-62.

\begin{tabular}{|c|c|c|c|c|c|c|}
\hline \multirow{2}{*}{ Treatment } & \multicolumn{3}{|c|}{ PGRs $\left(\mathrm{mg} \mathrm{l}^{-1}\right)$} & \multirow{2}{*}{$\begin{array}{l}\text { Frequency of type I } \\
\text { callus produced }(\%)^{\mathrm{a}}\end{array}$} & \multirow{2}{*}{$\begin{array}{l}\text { Frequency of type II } \\
\text { callus produced (\%) }^{\mathrm{a}}\end{array}$} & \multirow{2}{*}{$\begin{array}{l}\text { Frequency of type III } \\
\text { callus produced (\%) }\end{array}$} \\
\hline & 2, 4-D & KT & 6-BA & & & \\
\hline $\mathrm{MS}_{1}$ & 0 & 0 & 0 & 0 & 0 & 0 \\
\hline $\mathrm{MS}_{2}$ & 0 & 1 & 0.2 & $14.47 \pm 0.81^{b}$ & $2.12 \pm 0.51$ & $51.90 \pm 2.11$ \\
\hline $\mathrm{MS}_{3}$ & 0 & 3 & 0.5 & $8.72 \pm 1.60$ & $9.49 \pm 1.60$ & $41.67 \pm 4.22$ \\
\hline $\mathrm{MS}_{4}$ & 0 & 5 & 1 & $21.79 \pm 0.44$ & $6.41 \pm 1.17$ & $13.08 \pm 0.77$ \\
\hline $\mathrm{MS}_{5}$ & 2 & 0 & 0.2 & $10.00 \pm 0.00$ & $6.81 \pm 0.64$ & $2.45 \pm 2.21$ \\
\hline $\mathrm{MS}_{6}$ & 2 & 1 & 0 & $13.27 \pm 0.93$ & $13.48 \pm 1.07$ & $1.67 \pm 1.44$ \\
\hline $\mathrm{MS}_{7}$ & 2 & 3 & 1 & $13.33 \pm 2.22$ & $7.41 \pm 2.57$ & 0 \\
\hline $\mathrm{MS}_{8}$ & 2 & 5 & 0.5 & $15.00 \pm 3.33$ & $9.44 \pm 0.96$ & $2.28 \pm 0.96$ \\
\hline $\mathrm{MS}_{9}$ & 5 & 0 & 0.5 & $16.27 \pm 0.78$ & $12.85 \pm 1.69$ & $1.88 \pm 0.10$ \\
\hline $\mathrm{MS}_{10}$ & 5 & 1 & 1 & $16.09 \pm 1.14$ & $13.91 \pm 1.14$ & $0.67 \pm 0.57$ \\
\hline $\mathrm{MS}_{11}$ & 5 & 3 & 0 & $25.19 \pm 1.29$ & $18.01 \pm 1.89$ & 0 \\
\hline $\mathrm{MS}_{12}$ & 5 & 5 & 0.2 & $17.78 \pm 5.09$ & $3.33 \pm 0.00$ & 0 \\
\hline $\mathrm{MS}_{13}$ & 10 & 0 & 1 & $14.44 \pm 2.55$ & $16.11 \pm 3.85$ & 0 \\
\hline $\mathrm{MS}_{14}$ & 10 & 1 & 0.5 & $23.33 \pm 3.82$ & $5.00 \pm 4.33$ & $1.67 \pm 1.44$ \\
\hline $\mathrm{MS}_{15}$ & 10 & 3 & 0.2 & $28.33 \pm 10.10$ & 0 & 0 \\
\hline \multirow[t]{4}{*}{$\mathrm{MS}_{16}$} & 10 & 5 & 0 & $20.00 \pm 3.33$ & 0 & 0 \\
\hline & & & & $11.70^{* \mathrm{bc}}(P<0.0001)$ & $9.32^{* \mathrm{bc}}(P=0.0001)$ & $30.00^{\star \mathrm{bc}}(P<0.0001)$ \\
\hline & & & & $10.11^{\star \mathrm{bd}}(P<0.0001)$ & $1.51^{\mathrm{bd}}(P=0.2290)$ & $4.92^{\star \mathrm{bd}}(P=0.0058)$ \\
\hline & & & & $2.48^{\text {be }} \quad(P<0.0763)$ & $7.20^{* \mathrm{be}}(P=0.0007)$ & $9.43^{\star \mathrm{be}}(P<0.0001)$ \\
\hline
\end{tabular}

*Significantly different at $\mathrm{P}=0.05$; ${ }^{\mathrm{T}}$ Two-month culture; ${ }^{\mathrm{b}}$ percentage data are arcsine transformed when analyse with SAS program; ${ }^{\mathrm{c}} \mathrm{F}$-value of $2,4-\mathrm{D} ;{ }^{\mathrm{d}} \mathrm{F}$-value of $\mathrm{KT} ;{ }^{\mathrm{e}} \mathrm{F}$-value of 6 -BA.

6-BA but without 2,4-D among the sixteen media used in this study. The type I and II callus subcultured began to get brownish and finally died. However, the type III displayed active morphogenic growth (Figure 1b) and then was transferred onto the fresh medium monthly (Figure 1c).

\section{Somatic embryogenesis and plant regeneration}

Embryoids started to emerge and mature after type III callus was cultured for 6 - 8 weeks on embryo-induction medium (Figure 1d, e). About 4 somatic embryos per callus were obtained (Table 3). After mature embryos were cultured for $3-4$ weeks, approximately $11.8 \%$ of them developed into plantlets on the seedling emergence medium (Figure 1f) (data not shown). When the plantlets grew to $4-6 \mathrm{~cm}$, they were transplanted to sand bed and kept in a greenhouse for acclimatization, and then planted in small polybags with a mixture of soil and sand (Figure 1g).

\section{DISCUSSION}

Induction of callus in plants is affected by many factors, such as explants, PGRs and culture conditions. Among them, PGRs play a very key role. Furthermore, different concentrations and combinations of PGRs have significant effects on callus induction, which has been reported in many researches (Poeaim et al., 2005; Sun et al., 2006). In the present study, sixteen media with different concentrations of 2,4-D, 6-BA and KT were used to investigate the influences on three types of callus (I, II and III) formation (Table 1). Our results suggested that the sixteen hormonal combinations dramatically affected callus formation from root explants in $H$. brasiliensis. Selecting an appropriate hormonal combination is vital to successful induction of callus from different explants. In our research, the optimal hormonal combination is $1 \mathrm{mg} / \mathrm{l}$ $\mathrm{KT}$ and $0.2 \mathrm{mg} / \mathrm{l} \mathrm{6-BA}$ without 2,4-D (MS $)$, which led to the greatest frequency of embryogenic callus formation.

In addition, the results in this study revealed that 2,4-D was the most important PGR in callus induction, followed by $6-\mathrm{BA}$ and KT (Table 1). The frequency of embryogenic callus formation had a dramatic drop with the concentration of 2,4-D rising and reached highest when 2,4-D was absent (Table 2). It was reported, as in this study, that low concentration of 2,4-D is helpful for embryogenic callus formation from roots of Panax ginseng (Chang and Hsing, 1980) and Lycium barbarum (Hu et al., 2008), 
Table 2. Duncan's multiple range tests $(P=0.05)$ for different concentrations of $2,4-\mathrm{D}, \mathrm{KT}$ and $6-\mathrm{BA}$ on different types of callus induced.

\begin{tabular}{|c|c|c|c|c|c|c|c|c|c|c|c|}
\hline $\begin{array}{l}2,4-D \\
(\mathrm{mg} / \mathrm{I})\end{array}$ & $\begin{array}{c}\text { Mean of } \\
\text { type I }\end{array}$ & $\begin{array}{c}\text { Mean of } \\
\text { type II }\end{array}$ & $\begin{array}{c}\text { Mean of } \\
\text { type III }\end{array}$ & $\begin{array}{c}\mathrm{KT} \\
(\mathrm{mg} / \mathrm{I})\end{array}$ & $\begin{array}{c}\text { Mean of } \\
\text { type I }\end{array}$ & $\begin{array}{c}\text { Mean of } \\
\text { type II }\end{array}$ & $\begin{array}{c}\text { Mean of } \\
\text { type III }\end{array}$ & $\begin{array}{c}\text { 6-BA } \\
(\mathrm{mg} / \mathrm{I})\end{array}$ & $\begin{array}{c}\text { Mean of } \\
\text { type I }\end{array}$ & $\begin{array}{c}\text { Mean of } \\
\text { type II }\end{array}$ & $\begin{array}{c}\text { Mean of } \\
\text { type III }\end{array}$ \\
\hline 0 & $16.83 c^{d}$ & $10.21 b$ & $26.87 a$ & 0 & $16.13 b$ & $14.91 \mathrm{a}$ & $4.09 b$ & 0 & $19.50 \mathrm{~b}$ & $11.66 \mathrm{~b}$ & $1.52 b$ \\
\hline 2 & $20.97 b$ & $17.54 a$ & $6.00 \mathrm{~b}$ & 1 & $24.05 a$ & $15.58 \mathrm{a}$ & $15.51 \mathrm{a}$ & 0.2 & $24.37 a$ & $8.49 b$ & $13.64 a$ \\
\hline 5 & $25.59 a$ & $19.62 a$ & $2.93 b$ & 3 & $25.13 a$ & $14.65 a$ & $10.05 a b$ & 0.5 & 23.11ab & $16.84 a$ & $15.90 a$ \\
\hline 10 & $27.38 \mathrm{a}$ & $8.54 b$ & $1.52 \mathrm{~b}$ & 5 & $25.46 \mathrm{a}$ & $10.76 \mathrm{a}$ & 7.67b & 1 & $23.78 \mathrm{a}$ & $18.92 \mathrm{a}$ & $6.26 b$ \\
\hline
\end{tabular}

${ }^{\mathrm{d} P e r c e n t a g e}$ data are arcsine transformed when analysed with SAS program.

Table 3. The number of embryos produced per callus on the type II and type III.

\begin{tabular}{|l|c|}
\hline \multicolumn{1}{|c|}{ Type of callus } & $\begin{array}{c}\text { Number of embryos } \\
\text { produced per callus }\end{array}$ \\
\hline Type II & $0.09 \pm 0.04$ \\
Type III & $4.04 \pm 0.92$ \\
\hline
\end{tabular}

Values are the means \pm S.E. of three replicates.

whereas Wang found that high concentration of 2,4-D showed a promoting effect in Areca catechu (Wang et al., 2006). In H. brasiliensis, embryogenic callus from the pollen (Chen et al., 1979) and inner integument of the seed (Carron, 1981) was induced by high concentrations of 2,4-D. The result was opposite to those in this study. It may be due to different explants used. In this experiment, successful embryogenic callus induction in the absence of 2,4-D may relate to the level of endogenous hormones of roots from in vitro plantlets.

Higher concentration $(1 \mathrm{mg} / \mathrm{l})$ or absence of 6-BA resulted in lower induction frequency of embryogenic callus, which was in accordance with the results obtained in needles of redwood (Liu et al., 2006). It was reported that KT had a negative effect on callus induction (Zhao et al., 2010). This corresponded with the result in this study when the concentration of KT was in the range of $1-5 \mathrm{mg} /$ (Table 2).

In conclusion, the present study first established a system of somatic embryogenesis and plant regeneration from root explants of in vitro plantlets in $H$. brasiliensis. The system will facilitate mass propagation when applied to culture the roots of high-yielding rubber trees.

\section{ACKNOWLEDGEMENTS}

We thank Dr. Kun Yuan for critical reading of manu- script. This work was financially supported by the Natural Science Foundation of Hainan Province in China "Studies on the in vitro culture of the root and induction of callus of $H$. brasiliensis" (no. 30821) and the Special Fund of Basic Scientific Research of Rubber Research Institute of Chinese Academy of Tropical Agricultural Sciences "Studies on the in vitro culture of the root and its plant regeneration of $H$. brasiliensis" (no. XJSYWFZX2008-02).

\section{REFERENCES}

Ahmad B (1999). Effect of rootstock on growth and water use efficiency of Hevea during water stress. J. Rubber Res. 2 99-119.
Carron MP (1981). Germination in vitro d'embryons immatures d'hevea. Caoutch Plast. 612: p. 93.

Chang WC, Hsing YI (1980). Plant regeneration through somatic embryogenesis in root-derived callus of Ginseng (Panax ginseng C. Meyer A). Theor. Appl. Genet. 57: 133-135.

Chen ZH, Chen FT, Qian CF, Wang CH, Zhang SJ, Xu XE, Ou $\mathrm{XH}, \mathrm{He}$ YT, Lu ZM (1979). A process of obtaining pollen plants of Hevea brasiliensis Muell. Argon. Sci. Sin. 22: 81-90.

Hu Z, Hu Y, Gao HH, Guan XQ, Zhuang DH (2008). Callus production, somatic embryogenesis and plant regeneration of Lycium barbarum root explants. Biol. Plant. 52: 93-96.

Huang G, Lin W (2003). Biochemical Interaction between rootstock and scion of grafted Hevea brasiliensis. (In Chinese with English abstract). Chin. J. Trop. Crops, 24: 7-11.

Jayasree PK, Asokan MP, Sobha S, Sankari AL, Rekha K, Kala RG, Jayasree R, Thulaseedharan A (1999). Somatic embryogenesis and plant regeneration from immature anthers of Hevea brasiliensis (Muell. Arg.). Curr. Sci. 76: $1242-1245$.

Liu C, Xia X, Yin W, Huang L, Zhou J (2006). Shoot regeneration and somatic embryogenesis from needles of redwood (Sequoia sempervirens (D.Don.) Endl.). Plant Cell Rep. 25: 621-628.

Poeaim A, Matsuda Y, Murata T (2005). Plant regeneration from immature inflorescence of zoysiagrass (Zoysia spp.) Plant Biotechnol. 22: 245-248.

Sobhana P, Gopalakrishnan J, Jacob J, Sethuraj MR (2001). Physiological and biochemical aspects of stock-scion interaction in Hevea brasiliensis. Indian J. Nat. Rubber Res. 14: $131-136$

Sun Y, Zhang X, Huang C, Guo X, Nie Y (2006). Somatic embryogenesis and plant regeneration from different wild diploid cotton (Gossypium) species. Plant Cell Rep. 25: 
289-296.

Sushamakumari S, Sobha S, Rekha K, Jayasree R, Asokan MP (2000). Influence of growth regulators and sucrose on somatic embryogenesis from immature inflorescence of Hevea brasiliensis (Muell. Arg.). Indian J. Nat. Rubber Res. 13: 19-29.

Wang HC, Chen JT, Chang WC (2006). Somatic embryogenesisand plant regeneration from leaf, root and stem-derived callus cultures of Areca catechu. Biol. Planta. 50: 279-282.
Wang ZY, Zeng XS, Chen CQ, Wu HY, Li QY, Fan GJ, Lu WJ (1980). Induction of rubber plantlets from anther of Hevea brasiliensis Muell. Arg. in vitro. (In Chinese with English abstract). Chin. J. Trop Crops, 1: 16-25.

Zhao L, Liu S, Song S (2010). Optimization of callus induction and plant regeneration from germinating seeds of sweet sorghum (Sorghum bicolor Moench). Afr. J. Biotechnol. 9: 2367-2374. 